\title{
Comparative Effects of Monetary and Budgetary Policies on the Economy of Burkina Faso
}

\author{
Edmond Lankouandé \\ Department of Economics and Management, Thomas Sankara University, Ouagadougou, Burkina Faso \\ 01 BV 30214 Ouagadougou 01, Burkina Faso
}

\begin{abstract}
The article analyzes on three-time horizons the comparative effects of monetary and budgetary policies on the economy of Burkina Faso. It uses two models: error correction model and vector autoregressive model. Taking into account the passage from West African Monetary Union to West African Economic and Monetary Union and econometric results indicating a break in 1994 (year of the devaluation of the currency: XOF), the period of study 1970-2010 is split in two: 1970-1993 and 1994 -2010. The results show, on the economy of Burkina Faso, monetary policy has been more effective than budgetary policy in these three periods. From 1970 to 1993 , budgetary policy was ineffective on economic growth. On the period 1994-2010, the effects of monetary and budgetary policies have been weak and statistically insignificant. The devaluation of the XOF and the adoption of the Pact of Convergence of the WAEMU did not really contribute significantly to the country's economic growth.
\end{abstract}

Keywords: budgetary policy, monetary policy, error correction model, vector autoregressive model, Burkina Faso

DOI: $10.7176 / \mathrm{DCS} / 10-11-05$

Publication date: November $30^{\text {th }} 2020$

\section{Introduction}

The West African Monetary Union (WAMU), created in 1962, marks the determination of these member countries, currently eight, to stimulate their economies through monetary cooperation in order to get mutual benefits. Their monetary policy benefits relative stability because it escapes manipulation by public authorities. These countries achieved good economic performance during the period 1960-1970. However, in the 1980s, the economic situation in the area deteriorated. Indeed, the terms of trade deteriorated by around $45 \%$ between 1985 and 1992. To these difficulties were added the lack of harmonization and coordination between budgetary and monetary policies. It is in this context that the West African Economic and Monetary Union (WAEMU) was created in 1994 (Sarr and Ndiaye, 2010). Subsequently, in 1999, there was the adoption of the Pact of Convergence, Stability, Growth and Solidarity organized around criteria, which countries make an effort to be able to respect.

In Burkina Faso, despite these reforms, development indicators remain mixed. Burkina Faso is still ranked among those with a low human development index. Nevertheless, analysis of the economic growth rate indicates an improvement in growth levels. During the decade 1970-1979, the average annual growth rate of the country was estimated at $3.27 \% ; 3.74 \%$ the following decade, while it stood at 5.12\% during the period $1990-1999$ and finally at $5.37 \%$ from 2000 to 2010 . These economic performances could be explained by the strengthening of monetary union (1962: WAMU) by economic union (1994: WAEMU). Therefore, it is possible to think that budgetary policy regained its effectiveness from 1994. However, it would be difficult to attribute all these merits to it. Indeed, over the period 1994-1999 (before the adoption of the Pact of Convergence), the average annual growth rate was $6.51 \%$ per year. This rate could be explained by the effect of the devaluation of the currency (XOF) in 1994 which must have given Burkina Faso a certain boost in competitiveness.

Thus, Monetary and budgetary policies would be likely to propel and accelerate the economic growth of a country (Ndiaye, 2006). In the economic literature, the question of the implications and influences of monetary and budgetary policies on economic activity arises sharply. Each of these policies can increase or decrease aggregate demand over a period of time.

In the current context of the debates on the XOF, it is therefore important to research the comparative effects of monetary and budgetary policies on the economies of member countries of WAEMU. The article concerns Burkina Faso, which is one of the countries that are trying somehow to follow the Pact of Convergence but in terms of ranking according to the human development index has one of the lowest scores in the WAEMU. The analysis will be done according to different time horizons. Indeed, by distinguishing the periods of the study, it will be possible to see the contribution of the different economic reforms to economic growth.

The article is organized into five sections and introduction is the first. The secund deals with the literature review, the third concerns the methodology used and the fourth focuses on the results and the discussions generated. The last section concludes. 


\section{Literature review}

For neoclassical economists, public interventions are only necessary to ensure competitive markets and reduce institutional rigidities that prevent price flexibility. According to them, money is neutral in an economy. It only plays an intermediary role in the exchanges. As a result, monetary variables (especially in the long term) don't have a influence on relative prices and on real variables such as employment and production (Généreux, 2004). According to Keynes (1936), money is not just in demand for transactional reasons. It is also requested, on the one hand, for precautionary reasons and, on the other hand, for reasons of speculation. Budgetary and monetary policies, having a function of macroeconomic stabilization, then enable to amortize the random shocks that cause the economy to deviate from its growth path. Of the two policies, Keynes encourages public authorities to resort to budgetary policy. The crisis of the 1970s called Keynesian theories into question, because interventionist policies were becoming ineffective. Liberal theories then revive the debate with the advent of monetarist theses. Monetarist economists believe in the virtues of markets to self-regulate. However, they recognize market imperfections, but they don't believe that state intervention is effective in correcting them. For monetarists, the effects of monetary creation are temporary. In addition, short-term price rigidity gives way to a possible effectiveness of monetary policy. However, in the long term, as soon as agents adapt their behavior to the economic situation and prices become flexible, then monetary policy no longer has any effect on the real variables (production, employment). Therefore, discretionary policies should be avoided and the role of the state should be in the long term by promoting the functioning of markets.

To test the effectiveness of economic policies, studies have been carried out to assess their effects on economic activity. They focused more on industrialized countries before being applied to developing countries.

The study by Friedman and Meiselman (1963 cited by Ndiaye (2006)) shows that in the United States public expenditure does not has effect on the growth of output. Only monetary policy is more effective. This result is confirmed or disproved by other studies such as those of Andersen and Jordan (1968), Hafer (1982), Leeuw and Kalchbrenner (1969), Keran (1970), Batten and Hafer, and Jordan et al. (1999). These empirical works applied the St Louis model, developed by Andersen and Jordan (1968). The work of Andersen and Jordan (1968) focused on the effects of monetary and budgetary actions in stabilizing the United States economy for the period 1952-1968. The results show that monetary policy is more effective than budgetary policy on economic activity. Some economists, using this model or its modified version, have come up with mixed results. Leeuw and Kalchbrenner (1969) find that both policies are effective in the United States. The reflection of Keran (1970) on four countries (Germany, Canada, United States and France) reinforces doubts about the exclusive effectiveness of monetary policy. The study by Batten and Hafer (1983) of six industrialized countries (Germany, Canada, USA, France, Japan and United Kingdom) corroborates the conclusion of Keran (1970).

Other studies, drawing on the vector autoregressive model (VAR), have attempted to justify the effectiveness of budgetary policy and especially the interdependence between the two policies. There is the work of Ansari (1996), Blanchard and Perotti (1999), Perotti (2002), and Biau and Girard (2004). The study of Ansari (1996) on India for the period 1963-1993 shows the preponderance of budgetary policy over monetary action justifying the Keynesian thesis.

Studies on the effectiveness of the two policies in developing countries, particularly in Africa, remain relatively weak. Among these are the studies by Jordan et al. (1999), Jayaraman (2001), Ajisafe and Folorunso (2002), Adefeso and Mobolaji (2010), and Bynoe (1994). The study by Jordan et al. (1999) covers three Caribbean countries (Barbados, Trinidade and Tobago, Guyana). They test the comparative effectiveness of budgetary and monetary policies using a VAR. In Barbados, budgetary policy is effective and monetary policy ineffective. In Trinidade and Tobago, both are effective but in the short term. Guyana has the same result as the previous one. With regard to Africa, there is the work of Bynoe (1994), Ajisafe and Folorunso (2002) and Adefeso and Mobolaji (2010). The last two studies focus on Nigeria respectively for the periods 1970-1998 and 1970-2002. The authors conclude that monetary actions are superior to budgetary ones. However, they believe these policies are complementary. The research of Bynoe (1994) covering five countries (Ghana, Kenya, Nigeria, Sierra Leone and Tanzania) for a period of 1965-1990 yields mixed results. While monetary policy is dominant in Ghana, Nigeria and Sierra Leone, budgetary policy is only effective in Nigeria. In Kenya and Tanzania, the two policies remain unsuccessful, justifying the neoclassical thesis of the ineffectiveness of macroeconomic policies.

In the WAEMU, there is the work of Koné (1998, 2000), Nubukpo (2003 (1), 2003 (2)) and Ndiaye (2006) which have been identified. Ndiaye (2006) assesses the effectiveness of budgetary and monetary policies in Senegal using the error correction model (ECM) and VAR model. Data cover the period 1981-2003. The results show that both policies influence the economy of Senegal. However, budgetary policy represented by total revenue is more efficient than monetary policy in the short and long terms. On the other hand, the total expenditure variable has a reduced effect on economic activity. The results also show that inflation has a negative impact on economic growth. Koné $(1998,2000)$ assesses the impact of budgetary and monetary policies on the economic growth of WAEMU countries. The results reveal that both policies have a positive impact on 
countries' economies. However, monetary policy is more efficient; because it contributes to price stability while budgetary policy has been inflationary in some countries. The work of Nubukpo (2003 (1), 2003 (2)) relates respectively to the effectiveness of the monetary policy of the Central Bank of West African States (BCEAO) and to the impact of public expenditure on WAEMU economies. Nubukpo (2003 (2)) finds that total public expenditure over the period 1965-2000 does not have a significant impact on growth in the majority of the WAEMU economies, in particular in Burkina Faso. In the short and long terms, the effects of total public expenditure are negative and not statistically significant on the economy of Burkina Faso.

\section{Methodology}

The ECM and VAR model are used to determine the effects of monetary and budgetary policies on economic activity. However, the ECM has the advantage of distinguishing of short-term effects from long-term ones. In addition to the link between economic policies and economic activity, the VAR model highlights the relationships between the different variables. Also, if the ECM will not be adequate it is possible to resort to VAR model.

The choice of variables is based on economic theory and empirical studies of the effectiveness of macroeconomic policies. Ndiaye (2006) uses total public expenditure, total public revenue, money supply and price level to explain the evolution of the economic activity in Senegal. Given the similarity of Senegal with Burkina Faso, the same variables are used. However, we must distinguish three periods in order to verify whether the change in policy that took place in 1994 influenced the Burkina Faso economy. Moreover, to reduce the order of magnitude of the variables, they will be taken in logarithm except for the indicator variable DUM, marking the break if there are any:

- the logarithm of the gross domestic product in nominal terms (LGDP) as a proxy for economic activity;

- the logarithm of total public expenditure (LDT) and the logarithm of total public revenue (LRT) represent the effects of budgetary policy;

- the logarithm of the money supply $\mathrm{M}_{2}$ (LMM) represents the effects of monetary policy;

- the influence of prices is given by the logarithm consumer price index (LIPC);

- the indicator variable DUM $=1$ for the dates of rupture and DUM $=0$ elsewhere.

The study is being carried out over the period 1970-2010 due to the availability of data. This period covers practically a whole life of economic sovereignty marked by major changes in the conduct of economic policies. Data on the nominal GDP, total public expenditure and total public revenue variables come from the BCEAO database. Data on money supply $\left(\mathrm{M}_{2}\right)$ and the consumer price index are taken from the World Bank database.

With ECM and VAR model, the variables must be stationary. Moreover, ECM cannot be formulated without there being a relation of cointegration. Therefore, stationarity and cointegration tests as well as others will be carried out. Finally, the VAR will be used in the event that the ECM is not suitable.

* ECM equations

There are two types of ECM: Angle-Granger representation which is estimated in two phases and the Hendry representation in one step. Here, the ECM following the methodology of Hendry et al. (1978) is adapted.

Period 1970-2010:

$\overline{D L G D P_{\mathrm{t}}}=\alpha_{0}+\alpha_{1} L D T_{\mathrm{t}}+\alpha_{2} L R T_{\mathrm{t}}+$

$\alpha_{3} D L M M_{\mathrm{t}}+\alpha_{4} D L I P C_{\mathrm{t}}+\alpha_{5} L G D P_{\mathrm{t}-1}+\alpha_{6} L D T_{\mathrm{t}-1}+\alpha_{7} L R T_{\mathrm{t}-1}+\alpha_{8} L M M_{\mathrm{t}-1}+\alpha_{9} L I P C_{\mathrm{t}-1}+\varepsilon_{\mathrm{t}}$

(ECM 1)

Period 1970-1993:

$D L G D P_{t}=\beta_{0}+\beta_{1} D L D T_{t}+\beta_{2} D L R T_{t}$

$\beta_{3} L M M_{\mathrm{t}}+\beta_{4} L I P C_{\mathrm{t}}+\beta_{5} L G D P_{\mathrm{t}-1}+\beta_{6} L D T_{\mathrm{t}-1}+\beta_{7} L R T_{\mathrm{t}-1}+\beta_{8} L M M_{\mathrm{t}-1}+\beta_{9} L I P C_{\mathrm{t}-1}+\mu_{\mathrm{t}}$

(ECM 2)

Period 1994-2010:

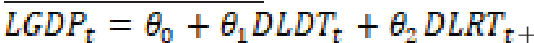

$\theta_{3} D L M M_{\mathrm{t}}+\theta_{4} D L I P C_{\mathrm{t}}+\theta_{5} L G D P_{\mathrm{t}-1}+\theta_{6} L D T_{\mathrm{t}-1}+\theta_{7} L R T_{\mathrm{t}-1}+\theta_{8} L M M_{\mathrm{t}-1}+\theta_{9} L I P C_{\mathrm{t}-1}+\vartheta_{\mathrm{t}}$

(ECM 3)

$\mathrm{D}$ is the first difference operator defined by $D Y_{\mathrm{t}}=Y_{\mathrm{t}}-Y_{\mathrm{t}-1}$.

* VAR (p) standard equation

$Y_{t}=\left(L P I B_{t} ; L M M_{t} ; L D_{t} ; L R_{t} ; L I P C_{t}\right)^{\prime}$ matrix of stationary dimension variables $(5 \times 1)$.

$Y_{t-p}=\left(L P I B_{t-p} ; L M M_{t-p} ; L D_{t-p} ; L R_{t-p} ; L I P C_{t-p}\right)^{\prime} ;$ matrix of lagged variables of dimension $(5 \times 1)$ with

$p$ is the optimal delay.

$\Gamma_{0}=$ dimension constant vector $(5 \times 1)$ et $\Gamma_{i}=$ matrix of dimension $(5 \times 5) i=1, \ldots, 4$.

$\varepsilon_{\mathrm{t}}=\left(\varepsilon_{\mathrm{t}}^{1} ; \varepsilon_{\mathrm{t}}^{2} ; \varepsilon_{\mathrm{t}}^{3} ; \varepsilon_{\mathrm{t}}^{4} ; \varepsilon_{\mathrm{t}}^{5}\right)^{\prime}$ vector of structural shocks or disturbances; 
$E\left(\varepsilon_{t}\right)=0 ; \varepsilon_{t} \approx \operatorname{iidN}(0 ; \Sigma)$

The disruptions are exogenous or endogenous shocks affecting the Burkina Faso economy. The structural model is written:

$$
Y_{t}=\Gamma_{0}+\Gamma_{i} Y_{t-p}+\varepsilon_{t}
$$

(VAR (p))

\section{Results and discussions}

4.1 Econometric analysis: period 1970-2010

Table 1: MCE estimation results: 1970-2010

\begin{tabular}{lllll}
\hline Variable & Coefficient & Std. Error & t-Statistic & Prob. \\
LDT & -0.151860 & 0.133897 & -1.134152 & 0.2657 \\
LRT & -0.036287 & 0.138062 & -0.262833 & 0.7945 \\
DLMM & 0.143087 & 0.146285 & 0.978141 & 0.3358 \\
DLIPC & 0.243930 & 0.285158 & 0.855419 & 0.3991 \\
LGDP(-1) & $\mathbf{- 0 . 4 4 5 8 3}$ & $\mathbf{0 . 1 0 2 2 7 0}$ & $\mathbf{- 4 . 3 5 9 3 7 6}$ & $\mathbf{0 . 0 0 0 1 * * *}$ \\
LDT(-1) & 0.026500 & 0.103655 & 0.255657 & 0.8000 \\
LRT(-1) & 0.015353 & 0.155636 & 0.098647 & 0.9221 \\
LMM(-1) & 0.319326 & 0.113400 & 2.815929 & $0.0085^{* * *}$ \\
LIPC(-1) & 0.496605 & 0.261126 & 1.901786 & $0.0668 *$ \\
C & 0.178481 & 0.514394 & 0.346973 & 0.7310 \\
R-squared & 0.457686 & Mean dependent var & 0.096744 \\
Adjusted R-squared & 0.294992 & S.D. dependent var & 0.108865 \\
S.E. of regression & 0.091408 & Akaike info criterion & -1.734642 \\
Sum squared resid & 0.250664 & Schwarz criterion & -1.312422 \\
Log likelihood & 44.69285 & F-statistic & 2.813172 \\
Durbin-Watson stat & 2.172458 & Prob(F-statistic) & 0.015973 \\
\hline
\end{tabular}

$(*)$ and $(* * *)$ indicate the respectively significant parameters at the thresholds $10 \%$ and $1 \%$

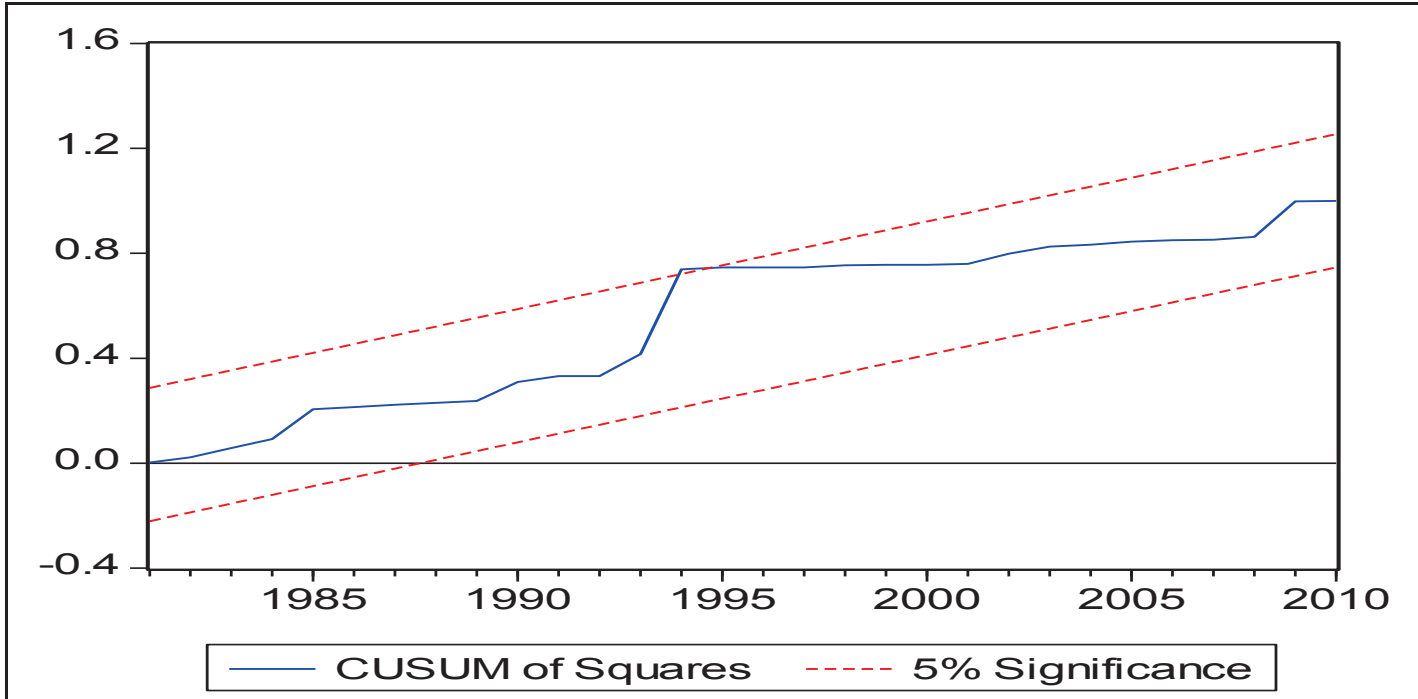

Figure 1: test CUSUM (period 1970-2010)

Table 1 indicates that the error correction coefficient is significantly negative. The stability test on the coefficients (CUSUM test of Brown, Durbin and Ewans (1975)) indicates the presence of rupture in 1994 (Figure 1). The model coefficients are then unstable. Therefore, ECM is punctually unstable.

To stabilize the model, an indicator variable is introduced: DUM $=1$ in 1994 and DUM $=0$ elsewhere. The estimate of ECM with the indicator variable DUM is given in Table 3. The coefficient of the variable DUM is significant at the 5\% level. The introduction of the indicator variable modifies the coefficients of the previous estimate and ECM with an indicator variable has a greater explanatory power than the first model. Before interpreting the results, tests should be carried out on the residues. 
* Tests of homoscedasticity, correlation, normality and stationarity of errors

Table 2: summary tests of ARCH, Breusch-Godfrey, Jarque-Bera and ADF: 1970-2010

\begin{tabular}{|c|c|c|c|c|c|c|c|c|}
\hline \multicolumn{3}{|c|}{$\mathrm{ARCH}$} & \multicolumn{2}{|c|}{ Breusch-Godfrey } & \multicolumn{2}{|c|}{ Jarque-Bera } & \multicolumn{2}{|c|}{$\mathrm{ADF}$} \\
\hline F-statistic & $\begin{array}{l}\text { Obs* } \\
\text { squared }\end{array}$ & R- & F-statistic & $\begin{array}{l}\text { Obs* } \\
\text { squared }\end{array}$ & $\begin{array}{l}\text { Jarque- } \\
\text { Bera }\end{array}$ & Probability & $\begin{array}{l}\mathrm{t}- \\
\text { Statistic }\end{array}$ & Probability \\
\hline $0.56532 * *$ & $0.55321 * *$ & & $0.84118 * *$ & $0.775243 * *$ & 1.57974 & $0.453902 * *$ & -6.7710 & $0.0000 * * *$ \\
\hline
\end{tabular}

From Table 2, it emerges that tests of ARCH, Breusch-Godfrey and Jarque-Bera reveal probability values greater than 5\%. Therefore, errors are respectively homoscedastic, uncorrelated and the assumption of normality of errors is accepted. The test ADF shows a probability value less than $1 \%$. Therefore, the residues are stationary. From these characteristics of the residuals, the model is optimal and the results seem robust. It is then possible to interpret the results (Table 3).

* Coefficient of restoring force

Table 3: MCE estimation results with an indicator variable: 1970-2010

\begin{tabular}{lllll}
\hline Variable & Coefficient & Std. Error & t-Statistic & Prob. \\
LDT & -0.246237 & 0.131738 & -1.869142 & $0.0717 *$ \\
LRT & 0.036432 & 0.132905 & 0.274123 & 0.7859 \\
DLMM & 0.110367 & 0.137527 & 0.802513 & 0.4288 \\
DLIPC & -0.116526 & 0.309160 & -0.376910 & 0.7090 \\
LGDP(-1) & $\mathbf{- 0 . 4 9 8 4 7}$ & $\mathbf{0 . 0 9 8 3 2 5}$ & $\mathbf{- 5 . 0 6 9 6 7 6}$ & $\mathbf{0 . 0 0 0 0 * * *}$ \\
LDT(-1) & 0.010884 & 0.097165 & 0.112013 & 0.9116 \\
LRT(-1) & 0.120385 & 0.152509 & 0.789363 & 0.4363 \\
LMM(-1) & 0.324583 & 0.106065 & 3.060219 & $0.0047^{* * *}$ \\
LIPC(-1) & 0.450057 & 0.245014 & 1.836860 & $0.0765 *$ \\
DUM & 0.248448 & 0.107834 & 2.303988 & $0.0286 * *$ \\
C & 0.386450 & 0.489409 & 0.789627 & 0.4362 \\
R-squared & 0.541596 & Mean dependent var & 0.096744 \\
Adjusted R-squared & 0.383525 & S.D. dependent var & 0.108865 \\
S.E. of regression & 0.085476 & Akaike info criterion & -1.852736 \\
Sum squared resid & 0.211880 & Schwarz criterion & -1.388294 \\
Log likelihood & 48.05471 & F-statistic & 3.426295 \\
Durbin-Watson stat & 2.106523 & Prob(F-statistic) & 0.004565 \\
\hline
\end{tabular}

$(*),(* *)$ and $(* * *)$ indicate the respectively significant parameters at the thresholds $10 \%, 5 \%$ and $1 \%$ The restoring force $\alpha_{5}=-0.498474$ is negative and significantly different from 0 at the threshold $1 \%$. Almost half $(49.8474 \%)$ of the imbalance in economic activity (GDP) is absorbed the year following the shock. In the event of a shock, the stabilization mechanism allows it to be absorbed after two years $(1 /-0.498474 \approx 2)$.

* Short-term elasticities

The budgetary policy represented by total public expenditure has been ineffective on the Burkina Faso economy. Represented by total public revenue, budgetary policy has positively influenced economic activity. Regarding monetary policy, it positively influenced of the economy of Burkina Faso. In the short-term, this monetary policy has a positive effect $(0.110367)$ greater than that of budgetary policy represented by total public revenue $(0.036432)$.

* Long-term elasticities

Both economic policies have made a positive contribution to increasing economic activity. The effect of monetary policy $(0.651153)$ remains greater than that of budgetary policy $(0.021843$ for DT and 0.241507 for RT). As in the short-term, in the long-term, monetary policy has been more effective than budgetary policy.

\subsection{Econometric analysis: period 1970-1993}

* Tests of homoscedasticity, correlation, normality and stationarity of errors

Table 4: summary tests of the ARCH, Breusch-Godfrey, Jarque-Bera and ADF: 1970-2010

\begin{tabular}{|c|c|c|c|c|c|c|c|c|c|}
\hline \multicolumn{3}{|c|}{$\mathrm{ARCH}$} & \multicolumn{3}{|c|}{ Breusch-Godfrey } & \multicolumn{2}{|c|}{ Jarque-Bera } & \multicolumn{2}{|c|}{$\mathrm{ADF}$} \\
\hline F-statistic & $\begin{array}{l}\text { Obs* } \\
\text { squared }\end{array}$ & R- & F-statistic & $\begin{array}{l}\text { Obs* } \\
\text { squared }\end{array}$ & R- & $\begin{array}{l}\text { Jarque- } \\
\text { Bera }\end{array}$ & Probability & $\begin{array}{l}\mathrm{t}- \\
\text { Statistic }\end{array}$ & Probability \\
\hline $0.3528 * *$ & $0.3291 * *$ & & $0.4486 * *$ & $0.2102 * *$ & & 0.2870 & $0.8663 * *$ & -4.864 & $0.0042 * * *$ \\
\hline
\end{tabular}

Table 4 indicates that the errors are homoscedastic and uncorrelated. The residues are stationary. The interpretation of the results is made in the following point from Table 5. 
Table 5: MCE estimation results: 1970-1993

\begin{tabular}{lllll}
\hline Variable & Coefficient & Std. Error & t-Statistic & Prob. \\
DLDT & -0.151434 & 0.171301 & -0.884027 & 0.3927 \\
DLRT & -0.097075 & 0.164346 & -0.590676 & 0.5649 \\
LMM & -0.297747 & 0.297065 & -1.002295 & 0.3345 \\
LIPC & 0.022323 & 0.407101 & 0.054835 & 0.9571 \\
LGDP(-1) & $\mathbf{- 0 . 6 4 8 1 4}$ & $\mathbf{0 . 1 3 1 8 0 5}$ & $\mathbf{- 4 . 9 1 7 4 5 1}$ & $\mathbf{0 . 0 0 0 3 * * *}$ \\
LDT(-1) & -0.134923 & 0.203993 & -0.661412 & 0.5199 \\
LRT(-1) & -0.064448 & 0.294776 & -0.218633 & 0.8303 \\
LMM(-1) & 0.607758 & 0.332276 & 1.829076 & $0.0904 *$ \\
LIPC(-1) & 0.836261 & 0.361129 & 2.315684 & $0.0375 * *$ \\
C & 0.338307 & 0.707816 & 0.477959 & 0.6406 \\
R-squared & 0.696217 & Mean dependent var & 0.100884 \\
Adjusted R-squared & 0.485906 & S.D. dependent var & 0.124936 \\
S.E. of regression & 0.089579 & Akaike info criterion & -1.688366 \\
Sum squared resid & 0.104318 & Schwarz criterion & -1.194673 \\
Log likelihood & 29.41621 & F-statistic & 3.310415 \\
Durbin-Watson stat & 2.186946 & Prob(F-statistic) & 0.025045 \\
\hline (***) indicate the respectively significant parameters at the thresholds $10 \%, 5 \%$ and $1 \%$
\end{tabular}

$(*),(* *)$ and $(* * *)$ indicate the

The restoring force $\beta_{5}=-0.648147$ is negative and significantly different from 0 at the threshold $1 \%$. Almost two-thirds of the imbalance in economic activity (GDP) is absorbed the year following the shock. In this specific case, the shock lasts for at least a year and half. This result is high to stabilize fluctuations in the economy of Burkina Faso. Compared to the period 1970-2010 when the shock lasts two years, this correction mechanism is faster.

* Short-term elasticities

In the short term, these two policies have been ineffective in stimulating the Burkina Faso economy. This seems to verify the neoclassical theses and those of rational expectations which postulate ineffectiveness of economic policies. This ineffectiveness can be attributed to the various crises which considerably affected the WAEMU countries: the oil shocks of the 1970s and the debt crisis of the 1980s.

* Long-term elasticities

Monetary policy has been effective only in the long-term, compared to the period 1970-2010 when it was effective both in the long and short terms. For budgetary policy, the difference is significant over these two periods. From 1970 to 1993, budgetary policy rests ineffective in the long and short terms on both the total public expenditure and total public revenue side. On the other hand, over the period 1970-2010 budgetary policy was ineffective, only on the side of short-term for total public expenditure.

\subsection{Econometric analysis: period 1994-2010}

Table 6: MCE estimation results: 1994-2010

\begin{tabular}{lllll}
\hline Variable & Coefficient & Std. Error & t-Statistic & Prob. \\
DLDT & -0.535323 & 0.435143 & -1.230223 & 0.2647 \\
DLRT & $-9.94 \mathrm{E}-05$ & 0.364849 & -0.000273 & 0.9998 \\
DLMM & 0.561602 & 0.174608 & 3.216364 & $0.0182^{* *}$ \\
DLIPC & -0.399381 & 0.726032 & -0.550087 & 0.6021 \\
LGDP(-1) & $\mathbf{0 . 2 0 7 8 0 3}$ & $\mathbf{0 . 2 6 4 8 4 4}$ & $\mathbf{0 . 7 8 4 6 2 4}$ & $\mathbf{0 . 4 6 2 5}$ \\
LDT(-1) & 0.418344 & 0.495044 & 0.845063 & 0.4305 \\
LRT(-1) & -1.308142 & 0.566644 & -2.308577 & $0.0604^{*}$ \\
LMM(-1) & 0.793656 & 0.301539 & 2.632019 & $0.0390^{* *}$ \\
LIPC(-1) & 2.033891 & 0.770919 & 2.638270 & $0.0386 * *$ \\
C & -2.586311 & 2.441999 & -1.059096 & 0.3303 \\
R-squared & 0.991958 & Mean dependent var & 7.749393 \\
Adjusted R-squared & 0.979895 & S.D. dependent var & 0.338192 \\
S.E. of regression & 0.047953 & Akaike info criterion & -2.968023 \\
Sum squared resid & 0.013797 & Schwarz criterion & -2.485155 \\
Log likelihood & 33.74418 & F-statistic & 82.23174 \\
Durbin-Watson stat & 2.289444 & Prob(F-statistic) & 0.000014 \\
\hline
\end{tabular}

$(*)$ and (**) indicate the respectively significant parameters at the thresholds $10 \%$ and $5 \%$

Results in Table 6 show that ECM is not valid; because the error correction coefficient is positive. 
According to Thiombiano (2002), the explanation may come from the size of the period (17) less than the required size (20). It is then necessary to resort to the VAR model. It is estimated and the Granger causality test is applied. LGDP is stationary in level while LDT, LRT, LMM and LIPC are stationary in first difference. The estimates indicate an optimal delay equal to 1 . The estimate of the unrestricted VAR (1) is given by the table below.

Table 7: Summary of estimation results of the VAR (1)

\begin{tabular}{|c|c|c|c|c|c|c|c|c|c|c|}
\hline \multirow{2}{*}{ Variable } & \multicolumn{2}{|c|}{ LPIB } & \multicolumn{2}{|c|}{ DLDT } & \multicolumn{2}{|c|}{ DLRT } & \multicolumn{2}{|c|}{ DLMM } & \multicolumn{2}{|c|}{ DLIPC } \\
\hline & Coef & t-stat & Coef & t-stat & Coef & t-stat & Coef & t-stat & Coef & t-stat \\
\hline LGDP(-1) & $1.0167 * * *$ & 14.61 & 0.0609 & 0.856 & 0.0639 & 0.953 & 0.0455 & 0.384 & -0.0143 & -0.47 \\
\hline DLDT(-1) & 0.0416 & 0.090 & 0.0601 & 0.127 & 0.5471 & 1.227 & $-1.5624 *$ & -1.98 & 0.0468 & 0.231 \\
\hline DLRT(-1) & -0.2989 & -0.74 & -0.0510 & -0.12 & -0.3524 & -0.91 & $1.4838 * *$ & 2.178 & -0.1124 & -0.64 \\
\hline DLMM(-1) & 0.1688 & 1.097 & 0.0552 & 0.351 & 0.0765 & 0.51 & -0.1779 & -0.67 & 0.0870 & 1.293 \\
\hline DLIPC(-1) & 0.8318 & 1.057 & $2.3429 * *$ & 2.909 & $2.830 * * *$ & 3.73 & -1.1412 & -0.85 & -0.2400 & -0.69 \\
\hline $\mathbf{R}^{2}$ & \multicolumn{2}{|c|}{0.9601} & \multicolumn{2}{|c|}{0.5826} & \multicolumn{2}{|c|}{0.6428} & \multicolumn{2}{|c|}{0.3681} & \multicolumn{2}{|c|}{0.2580} \\
\hline
\end{tabular}

$(*),(* *)$ and $(* * *)$ indicate the respectively significant parameters at the thresholds $10 \%, 5 \%$ and $1 \%$

Coef: coefficient et t-stat: t-statistic.

The estimation results indicate that the budgetary policy represented by total public revenue has acted negatively on the economy of Burkina Faso. Represented by total public expenditure, budgetary policy has positively influenced the economy of Burkina Faso as has monetary policy. The results also show that the effect of monetary policy $(0.1688)$ on GDP dominates those of budgetary policy $(0.0416$ for DT and -0.2989 for RT).

\subsection{Summary of estimation results and discussions}

Table 8: Summary of the results of the three estimates

\begin{tabular}{|c|c|c|c|c|c|}
\hline \multicolumn{6}{|c|}{ Period 1970-2010 } \\
\hline Policy & Variable & Short-term elasticity & Long-term elasticity & \multicolumn{2}{|c|}{ Efficacity } \\
\hline Monetary policy & LMM & 0.11036 & $0.65115^{* * *}$ & Yes & Yes \\
\hline \multirow{2}{*}{ Budgetary policy } & LDT & $-0.24623 *$ & 0.02184 & No & Yes \\
\hline & LRT & 0.03643 & 0.24150 & Yes & Yes \\
\hline \multicolumn{6}{|c|}{ Period 1970-1993 } \\
\hline \multirow{2}{*}{ Policy } & \multirow{2}{*}{ Variable } & \multirow{2}{*}{ Short-term elasticity } & \multirow{2}{*}{ Long-term elasticity } & \multicolumn{2}{|c|}{ Efficacity } \\
\hline & & & & Short-term & Long-term \\
\hline vonetary poncy & LIMIM & $-0.291 / 4$ & $0.93 / 68^{*}$ & No & Yes \\
\hline \multirow{2}{*}{ Budgetary policy } & LDT & -0.15143 & -0.20816 & No & No \\
\hline & LRT & -0.09707 & -0.00994 & No & No \\
\hline \multicolumn{6}{|c|}{ Period 1994-2010 } \\
\hline Policy & Variable & \multicolumn{2}{|c|}{ Coefficient } & \multicolumn{2}{|c|}{ Efficacity } \\
\hline Monetary policy & LMM & 0.16883 & & Yes & \\
\hline Budoetary nolicy & LDT & 0.04165 & & Yes & \\
\hline Buogetary poncy & LRT & -0.29895 & & No & \\
\hline
\end{tabular}

$(*)$ and $(* * *)$ indicate the respectively significant parameters at the thresholds $10 \%$ and $1 \%$

On all three periods, monetary policy has remained effective. Its effects have remained greater than those of budgetary policy. On forty years (1970-2010), the economy of Burkina Faso has been driven by monetary policy, ceteris paribus. The most evocative case is that of the period 1970-1993. On this period, budgetary policy has been exclusively ineffective in increasing GDP. This explains the predominance of monetary policy on this period. This period was marked by two oil shocks, the debt crisis and the application of structural adjustment programs. These factors have not been such as to allow budgetary policy to have a positive effect on the economy of the country. Indeed, apart from the harmful effects of the oil shocks which limited the expected effects of budgetary policy, Burkina Faso, like the other WAEMU countries, conducted its budgetary policy in a lax manner. This situation has led international institutions to impose rigor in the management of its budget on the country. The restriction on public expenditure does not appear to have worked.

In addition, on the periods 1970-2010 and 1970-1993, monetary policy was highly effective, it was exogenous. In other words, during these periods changes in past values of GDP, total public expenditure and total public revenue did not allow better forecasts of the money supply to be made. This fact shows that the development of monetary policy has been influenced by international economic conditions. It is understandable that on the period 1970-1993 budgetary policy was ineffective. What is less acceptable is the fact that on the period 1994-2010 budgetary policy could not contribute significantly to economic growth. Moreover, represented by total public revenue, budgetary policy has had a negative effect on the economy of Burkina Faso. 
Moreover, it was expected that with the devaluation of 1994 and adoption of the Pact of Convergence in 1999, budgetary policy would regain its effectiveness, so much promoted by the Keynesians.

Nubukpo (2003 (2)) believes that the insignificant effects of total expenditure have an explanation. In an open economy, the Keynesian multiplier effect is limited if an economy's marginal propensity to import is high. Burkina Faso is a net importer of consumer goods. This partly explains the reduced effect of this total public expenditure, especially since the products of national companies are not sufficiently valued. Also, the question of the actual destination of the total expenditure arises. Their reduced effect may be attributable either to inefficient project finance, or this public expenditure has been diverted from its first destination. Indeed, Rajkumar et al. (2002) (cited by Nubukpo (2003 (2)) show that good governance has a positive impact on the efficiency of public expenditure.

Regarding total public revenue, in Burkina Faso as in the majority of developing countries, the mobilization of own resources is proving difficult. Although the Pact of the Convergence imposes at the countries a fiscal pressure of $17 \%$, WAEMU countries have still not achieved this. Likewise, the size of the informal sector in Burkina Faso is not likely to facilitate the collection of fiscal resources. In addition, current revenues cover about $80 \%$ of total revenues. One of the components of current revenues, apart from tax revenue, is export revenue. This component is encroached upon by the deterioration of the terms of trade. It appears that the total revenues are not sufficient to propel economic activity. In the final analysis, for the specific case of the 1994-2010 period, the non-significance of the parameters suggests that after 1994 the economy may have been influenced by structural policies.

\section{Conclusion and implications}

The objective of the article is a comparative analysis of the effects of monetary and budgetary policies on the economy of Burkina Faso. The effects of monetary and budgetary policies on different time horizons (1970-2010, 1970-1993 and 1994-2010) were determined. The analysis of short-term and long-term elasticities shows that monetary policy has acted positively on the economy of Burkina Faso with long-term effects greater than shortterm ones. budgetary policy represented by total public revenue has positively influenced the economic activity. While represented by total public expenditure, budgetary policy has been ineffective in the short-term. For the period 1994-2010, limited effects of the two economic policies raise a number of questions.

First, the issue of the devaluation of the XOF can be raised. Of course, the economic situation required a devaluation; but at what rate? Burkina Faso seems to have not benefited from the expected fallout from this devaluation. This reflects the fact that the country's exports are driven by raw materials, the prices of which are suffering the devastating effects of the deterioration of the terms of trade. Moreover, the devaluation does not seem to have helped to reduce the quantity of imported products. On the contrary, imports have increased and, with them, their prices. Second, this result may be attributable to the Pact of Convergence. In Burkina Faso, wages continued to increase more than revenues. As the debt must be less than or equal to $70 \%$ of nominal GDP, the country's ratio is around $35.40 \%$. So, in addition to having difficulties to increase its total public revenues and facing an increase in the wage bill (which is geared towards the consumption of foreign products), the country has less recourse to debt. Of course, debt, as in the 1980s, can be a source of economic slowdown. However, this situation should in no way hide the beneficial effects of debt when it is used to finance productive investments. Moreover, all industrialized and emerging countries are in debt and often more than $100 \%$ of their GDP. Also, Tanimoune (2005) shows that WAEMU countries can borrow up to $83 \%$ of their GDP and any indebtedness beyond this threshold cannot benefit from the multiplicative effects of budgetary action.

This article has brought out the comparative effects of monetary and budgetary policies on the economic of Burkina Faso in three-time dimensions. However, the country is a member of an economic and monetary union (WAEMU) which aims to harmonize national economic policies. Therefore, it is not consistent to ignore the interdependence of countries and especially when they are governed by the same monetary institution. Likewise, with the BCEAO's financial liberalization policy, the key interest rate has become its control parameter. Integrating the new vision of the BCEAO as well as the interdependence effect of WAEMU member countries in determining the effects of monetary and budgetary policies could constitute a complementary research line.

\section{References}

Adefeso, H.A. \& Mobolaji, H.I. (2010). The Fiscal-Monetary Policy and Economic Growth in Nigeria: Further Empirical Evidence. Pakistan Journal of Social Sciences. Vol.7. N². pp.137-142.

Ajisafe, R.A. \& Folorunso, B.A. (2002). The Relative Effectiveness of Fiscal and Monetary Policy in Macroeconomic Management in Nigeria. The African Economic and Business Review. Vol.3. N¹. Spring.

Andersen L.C. \& Jordan, J.L. (1968). Monetary and Fiscal Actions: A Test of Their Relative Importance in Economic Stabilization. Federal Reserve of St. Louis Review. November.

Ansari, M.I. (1996). Monetary vs. Fiscal Policy: Some Evidence from Vector Autoregression for India. Journal of Asian Economic. Vol.7. N4. pp.677-698. 
Batten, D.S. \& Hafer, R.W. (1983). The Relative Impact of Monetary and Fiscal Actions on Economic Activity: A Cross-Country Comparison. Federal Reserve Bank of St. Louis Review. January.

Biau, O. \& Girard, E. (2004). Politique budgétaire et dynamique économique en France: l'approche VAR structurel. Economie et Prévision. N¹69-171. Septembre.

Blanchard, O. et Perotti, R. (1999). An Empirical Characterization of the Dynamic Effects of Changes in Government Spending and Taxes on Output. National Bureau of Economic Research. Working Paper $\mathrm{N}^{\circ} 7269$. JEL NE62-E32. July.

Hendry, D.F., Davidson, J.E.H., Srba, F. \& Yeo, S. (1978). Econometric Modelling of Aggregate Time-series Relationship Between Consumer's Expenditure and Income in the United Kingdom. The Economic Journal. Vol.88. N³52. pp.661-692. December.

Généreux, J. (2004). «Economie politique. 3. Macroéconomie ». Coll. Les Fondamentaux. Hachette. 4ème édition.

Hafer, R.W. (1982). The Role of Fiscal Policy in the St. Louis Equation. Federal Reserve Bank of St. Louis review. January.

Jayaraman, T.K. (2001). Efficacy of Fiscal and Monetary Policies in the South Pacific Island Countries: Some Empirical Evidence. The Indian Economic Journal. Vol.49. N¹. pp.63-72.

Jordan, A., Craigwell, R. \& Carter, A. (1999). The Potency of Monetary and Fiscal Policies in Caribbean Countries: a cointegrating VAR Approach. Research Department Central Bank of Barbados. October.

Keran, M.W. (1970). Monetary and Fiscal Influences on Economic Activity: The Foreign Experience. Federal Reserve Bank of St Louis Review. February.

Keynes, J.M. (1936). « Théorie Générale de l’Emploi, de l'Intérêt et de la Monnaie ». Traduit de l'anglais par Jean-de Largentaye. Editions Payot. Paris. 1942.

Koné, S. (2000). L'impact des politiques monétaire et budgétaire sur la croissance économique dans les pays de l'UEMOA. Document d'Etudes et de Recherches. N509. BCEAO. Décembre.

Koné, S. (1998). L'impact des politiques monétaire et budgétaire sur la croissance économique dans les pays de l'UEMOA. Document d'Etudes et de Recherches. NDER/98/03. BCEAO. Juin.

Leeuw, F. \& Kalchbrenner, J. (1969). Monetary and Fiscal Actions: A Test of Their Relative Importance in Economic Stabilization - Comment. Federal Reserve Bank of St Louis Review. April.

Ndiaye, C.T. (2006). Analyse de l'efficacité relative des politiques monétaire et budgétaire au Sénégal. Laboratoire d'Economie d'Orléans (LEO).

Nubukpo, K.K. (2003 (1)). L'efficacité de la politique monétaire de la Banque Centrale des Etats de l'Afrique de l'Ouest depuis la libéralisation de 1989. Centre de Coopération Internationale pour la Recherche et le Développement (CIRAD). Novembre.

Nubukpo, K.K. (2003 (2)). Impact des dépenses publiques sur la croissance des économies de l'Union Economique et Monétaire Ouest Africaine. Centre de Coopération Internationale pour la Recherche et le Développement (CIRAD). Décembre.

Perotti, R. (2002). Estimating the Effects of Fiscal Policy in OECD Countries. European Central Bank. Working paper $\mathrm{N}^{\circ} 168$. August.

Sarr, F. \& Ndiaye C.T. (2010). (A) Symétrie et convergence des politiques et chocs budgétaires en Zone UEMOA.

Tanimoune, N. A. et al. (2005). La politique budgétaire et ses effets de seuil sur l'activité en Union Economique et Monétaire Ouest Africaine (UEMOA). CERDI. Mai.

Thiombiano, T. (2008). « Econométrie des séries temporelles ». L’Harmattan Burkina Faso. 